\title{
ЗАКОНОДАТЕЛЬСТВО КРИМИНАЛЬНОГО ЦИКЛА КАК НОРМАТИВНАЯ ОСНОВА УГОЛОВНОЙ ПОЛИТИКИ
}

\begin{abstract}
Аннотация: В теории государства и права, отраслевых юридических науках - уголовном, уголовно-процессуальном, уголовно-исполнительном праве проблема определения понятия уголовной политики является фундаментальной. В статье рассмотрены вопросы отнесения законодательства криминального ијкла к элементам нормативной основы уголовной политики. Исследуется ретроспектива становления уголовной политики, дается новое определение такой политики.

Review: The problem of definition of criminal policy is fundamental for the theory of state and law, and branches of legal science (criminal law, criminal procedural law, penal law). The article concerns the issue of inclusion of the criminal cycle legislation into the system of elements of the normative basis of criminal policy. The author studies a retrospective of criminal policy and provides a new definition of such a policy.
\end{abstract}

Ключевые слова: Юриспруденция, политика, уголовная, законодательство, криминальный цикл, нормативная основа, уголовно-прочессуальное, уголовно-исполнительное, взаимосвязи, право

Keywords: jurisprudence, politics, criminal, legislation, criminal cycle, normative basis, criminal procedural, penal, interrelations, law.

теории государства и права, отраслевых юридических науках - уголовном, уголовнопроцессуальном, уголовно-исполнительном праве и науках, не представляющих самостоятельных отраслей права, но имеющих самостоятельный предмет (таких, например, как криминология) проблема определения понятия уголовной политики является фундаментальной.

Процесс формирования современного понятия уголовной политики охватывает значительный период времени в истории цивилизации.

Одно из первых упоминаний об уголовной политике можно встретить в начале XIX в. в работах виднейшего немецкого юриста Ансельма Фейербаха (1775-1833). Распространенным было мнение о том, что новая наука уголовной политики является как бы прикладной к догме уголовного права ${ }^{1}$, которая стояла на позиции признания преступного деяния как единичного, случайного, произвольного явления, которого ни предвидеть, ни предупредить было нельзя.

Однако впоследствии оценка преступности как явления, имеющего свои истоки, причины, количественные и качественные показатели, шло наряду с формированием политики как науки.

\footnotetext{
${ }^{1}$ Гогель С.К. Курс уголовной политики в связи с уголовной со-
} циологией. СПб., 1910. С. 1.
В начале XX в. русская юридическая наука не совсем ясно представляла себе суть уголовной политики. В целом ряде трудов, имеющих к ней отношение, были разработаны лишь отдельные вопросы, без систематической полноты и исторических экскурсов.

Наиболее полно исторический анализ появления уголовной политики был осуществлен известным правоведом того времени, профессором М.П. Чубинским в работе «Курс уголовной политики» ${ }^{2}$ М.П. Чубинский определял уголовную политику как «ветвь уголовного права для разработки улучшения правосознания политики» ${ }^{3}$. Эту точку зрения поддерживали и другие ученые ${ }^{4}$. Политический элемент применительно к уголовному праву появился достаточно давно, однако формирование уголовной политики как научной дисциплины имеет сравнительно небольшую историю.

А. Фейербах под уголовной политикой понимал ту ветвь науки, которая должна дать уголовному законодателю указания для лучшей организации дела правосудия 5 . И. Бентам возложил на науку

\footnotetext{
2 Чубинский М.П. Курс уголовной политики. СПб., 1912.

3 Чубинский М.П. Курс уголовной политики. СПб., 1912. С. 1.

${ }^{4}$ См.: Владимиров Л.Е. Курс уголовного права. М., 1908. С. 179-181.

${ }^{5}$ Feuerbach A. Versuch einer Criminaljurisprudenz des Koran, 1804. S. $163-165$.
} 
DOI: 10.7256/1811-9018.2013.9.2326

При цитировании этой статьи сноска на dоі обязательна

\section{Право и политика $9(165) \cdot 2013$}

уголовного права важнейшие уголовно-политические задачи. Она должна, по его мысли, изучать преступления и средства борьбы с ними, возводить в ранг преступлений всякое деяние, которому следует воспрепятствовать в виду вызываемого им или грозящего от него зла ${ }^{6}$. В свою широкую уголовнополитическую программу Бентам включал не только репрессию, но и превенцию.

А. Хенке ${ }^{7}$ перу которого принадлежит первый «Курс уголовного права и уголовной политики», считал, что уголовная политика должна удовлетворять сложным и вместе с тем трудно примиряемым требованиям: с одной стороны, видеть в преступнике человека и в каждом подозреваемом возможного невинного, а с другой - обеспечивать потребности общества в безопасности от преступных посягательств. Нетрудно заметить, что в данном высказывании большое значение отводится тому, что сегодня называется «презумпцией невиновности»- одним из основополагающих положений уголовного процесса.

В течение второй четверти XIX в. появлялись труды уголовно-политического характера (частью посвященные вопросу о предупреждении преступлений, частью содержащие различные проекты уголовного законодательства, частью критикующие законодательный материал).

В 50-е и 60-е годы XIX в. уголовная политика как нечто целое по-прежнему не пользовалась вниманием и не признавалась элементом науки уголовного права. Вопросы о том, что такое уголовная политика, какова сфера ее ведения и каково ее соотношение с уголовным правом, практически не ставились.

В последней четверти XIX в. в науке уголовного права уголовно-политическое движение проявилось в столь интенсивных формах и вызвало столько оживления и новых работ, что его можно сопоставить с широким уголовно-политическим движением последней четверти XVIII в. Уголовная политика впервые получила прочную научную основу, а вместе с ней и возможность более настойчиво добиваться признания ее полноправной частью науки уголовного права.

Уголовная политика, по мнению Ф. Листа, высказанному им в начале девяностых годов XIX в., есть та часть науки уголовного права, которая должна быть

\footnotetext{
${ }^{6}$ Цит. по: Чубинский М.П. Указ. соч. С. 4.

${ }^{7}$ Там же. С. 6.
}

«руководительницею уголовного законодательства». Опираясь на криминологию и пенологию, она должна развиваться вместе с уголовным правом ${ }^{8}$.

Во второй половине XIX в. в России стали говорить о расширении рамок науки уголовного права, особенно подчеркивая значение уголовно-политического элемента. Н.А. Неклюдов сформировал идею о том, что «Уголовная политика государства, основанная на уголовной статистике, будет государственная мудрость, против которой будет бессильна всякая борьба, потому что каждая такая мера, каждый такой закон будет, по прекрасному выражению Цицерона, non lata, sed nata, т. е. не созданным искусственно, но выработанным жизнью, а жизнь не может противодействовать своим же собственным потребностям и благу» ${ }^{9}$.

M.В. Духовской возложил на уголовное право «обязанность указывать государству средства для успешной борьбы с преступностью и для реорганизации карательных мер в духе отказа от теории возмездия». Он же убедительно подчеркнул то, что наука уголовного права «должна ведать превентивными мерами и не стесняться указанием необходимых социальных реформ», т. е. практически высказался за введение в науку уголовного права научно обоснованного уголовно-политического элемента.

У И.Я. Фойницкого нет определения термина «уголовная политика», но из разных положений его работ следует, что уголовная политика должна «вырабатывать указания для уголовного законодателя в деле наилучшей охраны правопорядка и целесообразно поставленной борьбы с преступностью» ${ }^{10}$.

А.А. Пионтковский отмечал «сложный состав» уголовно-правовой науки, в которую входят криминология, уголовная политика, уголовная догматика. Уголовная политика «...имеет своим предметом изучение средств борьбы с преступностью, а задачей - целесообразное построение этих средств» ${ }^{11}$.

В начале 20-х гг. ХХ в. в советской юридической литературе встречались первые попытки определить основные научные категории теории уголовной

\footnotetext{
${ }^{8}$ Цит. по: Лунеев В.В. Преступность ХХ века. Мировые, региональные и российские тенденции. М.: Издательство НОРМА, 1999. С. $12,15-16$.

${ }^{9}$ Цит. по: Чубинский М.П. Указ. соч. С. 12.

${ }^{10}$ Там же. С. 13.

${ }^{11}$ Пионтковский А.А. Наука уголовного права: его предмет, задачи и значение. Одесса, 1892. С. 11.
} 
DOI: $10.7256 / 1811-9018.2013 .9 .2326$

При цитировании этой статьи сноска на dоі обязательна

Закон и правопорядок

политики - ее предмет, метод, цели, задачи и т. д. Соответственно духу времени первостепенное внимание уделялось обоснованию классовой направленности практической уголовной политики.

В конце 20-х гг. была поставлена цель создания прочной общетеоретической и методологической базы для развития дисциплин уголовно-правового направления. В работах этого времени связь уголовной политики с законодательством криминального цикла означает связь и с другими, помимо уголовного права, отраслями законодательства. Так, по-прежнему обозначая прямую связь уголовной политики с уголовным правом, А.А. Пионтковский, сын известного русского юриста Андрея Антоновича Пионтковского, говорил, что «превращение уголовной политики пролетарского государства в науку является важнейшей задачей современной марксистской теории уголовного права». Однако он сформулировал и важный в методологическом отношении тезис о том, что нормы уголовного права, как и все законодательство о борьбе с преступностью (курсив наш - Д.Г., А.Ф.), призваны отражать определенные уголовно-политические требования. ${ }^{12}$

Как и прежде, с конца 20-х гг. ХХ в. уголовная политика была теснейшим образом связана с криминологическими исследованиями преступностями. В 1931 г. Государственный институт по изучению преступности и преступника был реорганизован в Институт уголовной и исправительно-трудовой политики. На долгие годы (с 1930 по конец 50-х гг.) криминологические исследования были по существу преданы забвению. Это, несомненно, способствовало активизации уголовно-политических исследований с соответствующей идеологической окраской.

В рамках теории уголовной политики в этот период исследовались проблемы наказания и классовой природы преступления ${ }^{13}$, а также «реакционной сущности буржуазной уголовной политики» ${ }^{14}$. «С точки

\footnotetext{
${ }^{12}$ Пионтковский А. А. Марксизм и уголовное право. - 2-е изд. - М.: Юрид. изд-во НКЮ РСФСР, 1929. С. 6. (См.: Он же. Советское уголовное право: Общая часть. М.: Юрид. изд-во НКЮ, 1928. С. 61).

${ }^{13}$ См., например: Волков Г.И. Классовая природа преступлений и советское уголовное право. М.: Советское законодательство, 1935. $226 \mathrm{c}$.

${ }^{14}$ См., например: Волков Г.И. Уголовная политика эпохи промышленного капитализма. М.: Сов. законодательство, 1932. 105 с.; Булатов С.Я. Уголовная политика эпохи империализма. М.: Сов. законодательство, 1933. 225 с.; Карательная политика капиталистических стран. М.: Сов. законодательство, 1933. 19 с.;
}

зрения материализма, писал в то время С.Я. Булатов, - уголовная политика, находящая свое выражение в работе таких материальных придатков государства, как суды, тюрьмы, особые отряды вооруженных людей... есть часть государственной политики...» ${ }^{15}$.

Уголовная политика как теория, будучи «идеологически скорректированной», в дальнейшем так и продолжала сохранять свое значение общетеоретической и методологической базы дисциплин уголовно-правового цикла. Однако по мере их развития, она находила свое выражение в разработках, относящихся непосредственно к уголовному праву, уголовному процессу и исправительно-трудовому праву, криминалистике, прокурорскому надзору и др., постепенно как бы растворяясь в них.

В середине 50-Х гг. ХХ в. практически официально - в Большой Советской Энциклопедии - отмечалось, что «социалистическая теория уголовного права не знает уголовной политики как особой научной дисциплины» ${ }^{16}$. С конца 30-х до конца 70-х гг. проблемы уголовной политики практически не разрабатывались.

Советские криминалисты обходили стороной уголовно-политические проблемы. Они «молчаливо исходили из того, что специальные меры борьбы с преступностью в основном исчерпываются (или должны исчерпываться) законодательной и правоприменительной деятельностью в области уголовного права. Уголовно-правовая наука сводила тогда свою функцию к комментированию действующего законодательства и судебных решений, к простой констатации фактов и не претендовала на разработку теоретических основ советского законодательства и карательной практики» ${ }^{17}$.

В рассматриваемый период постепенно свертывались исследования по наиболее общим проблемам борьбы с преступностью. В работах, относящихся к уголовному праву, уголовному процессу, исправительно-трудовому праву, криминалистике и др.,

Пионтковский A.А. Уголовная политика Японии. М.: Сов. законодательство, 1936. 232 с.

${ }^{15}$ Булатов С.Я. Указ. соч. С. 5.

${ }^{16}$ БСЭ. М., 1956. Т. 43. С. 619.

17 Исмаилов И.А. Уголовная политика как сложная система // Учен. зап. / Азербайджанский университет. Серия юридических наук. Баку, 1975. Вып. 1. С. 11, 14; см. также: Антонян Ю.М. Социалистическая законность и уголовная политика // XXVI съезд КПСС и укрепление законности и правопорядка. М.: ИГП АН CCCP, 1982. С. 17. 
DOI: 10.7256/1811-9018.2013.9.2326

При цитировании этой статьи сноска на dоі обязательна

\section{Право и политика 9 (165) • 2013}

почти не встречалось глубокого анализа социальных факторов, детерминирующих преступное поведение и меры борьбы с ним ${ }^{18}$.

Дифференциация уголовно-политических исследований по отдельным отраслям науки о борьбе с преступностью объяснялась не совсем четкими трактовками самой уголовной политики. Ведь до сих пор еще имеют место попытки охватить ее какой-либо одной уголовно-правовой дисциплиной: например, уголовным правом или криминологией либо обеими этими дисциплинами.

Ранее предлагалось, исходя из стремления избежать ненужного дублирования и сохранить стройность и полноту курса советского уголовного права, исследовать общие проблемы уголовной политики в рамках науки уголовного нрава, а отдельные ее вопросы отнести к предмету соответственно уголовно-процессуального и исправительно-трудового права ${ }^{19}$. Но уголовная политика по своей политикоправовой природе неделима. Она пронизывает уголовное право, уголовный процесс, уголовно-исполнительное право, криминологию, криминалистику и все другие дисциплины, имеющие то или иное отношение к решению задач борьбы с преступностью.

Большая часть уголовно-политических исследований традиционно осуществлялась в рамках только нормативно-правовых (уголовно-правовых, уголовно-процессуальных и уголовно-исполнительных) средств воздействия на преступность, без должного внимания к другим средствам нормативного регулирования ${ }^{20}$.

Сегодня одним из основных направлений разработки концепций борьбы с преступностью в нашей стране являются исследования в области уголовного, уголовно-процессуального, уголовноисполнительного законодательства.

Согласно Конституции России на всей территории Федерации действует единое уголовное, уголовно-процессуальное и уголовно-исполнительное законодательство. Это, однако, не исключает различий

\footnotetext{
18 Лесников Г.Ю. Уголовная политика современной России (методологические, правовые и организационные аспекты). Дисс. докт. юрид. наук. М. 2005. С. 81.

19 Загородников Н.И., Стручков Н.А. Направления изучения советского уголовного права // Советское государство и право. 1981. № 7. С. 49 .

20 Лесников Г.Ю. Уголовная политика современной России (методологические, правовые и организационные аспекты). Дисс. докт. юрид. наук. М. 2005. С. 159.
}

практики его применения в субъектах федерации. Часто это обусловлено существующими различиями в социально-экономической, демографической, культурно-исторической и других сферах жизнедеятельности территориальных образований, этнопсихологическими особенностями преступности, высоким в ряде регионов уровнем организованной преступности, а также степенью разработанности уголовно-политических мер в регионе.

Политика государства, направленная на борьбу с преступностью - уголовная политика - реализуется в изменениях, вносимых в уголовное право - материальное, процессуальное, исполнительное, а также в организации профилактических мероприятий по предупреждению преступности и ресоциализации преступников. Неслучайно поэтому то, что нормативная база уголовно-политических исследований включает, в частности, действующее уголовное, уголовно-процессуальное, уголовно-исполнительное ${ }^{21}$.

Уголовную политику предопределяют существующие условия борьбы с преступностью. Она выражается в создании и осуществлении системы государственно-политических указаний, норм материального, процессуального и исполнительного уголовного законодательства, норм ряда иных нормативных предписаний

Уголовная политика по отношению к материальным, процессуальным и исполнительным уголовноправовым отраслям права играет координирующую роль. Применение норм названных отраслей - это одна из форм реализации уголовной политики. Закономерным является то, что в юридической науке решения дальнейшего совершенствования уголовного, уголовно-процессуального и уголовно-исполнительного законодательства РФ предлагаются в контексте реформирования уголовной политики ${ }^{22}$.

Два основных подхода, связанные с широким и узким пониманием уголовной политики, сводятся к следующему.

Первый подход был сформулирован А.А. Герцензоном, считавшим, что изучаемым понятием охватывается все, что направлено на борьбу с преступностью. Он включал в сферу уголовной политики специальные меры (уголовно-правовые,

\footnotetext{
${ }^{21}$ Там же. С. 10.

22 Лесников Г.Ю. Уголовная политика современной России (методологические, правовые и организационные аспекты). Дисс. докт. юрид. наук. М. 2005. С. 16.
} 
DOI: $10.7256 / 1811-9018.2013 .9 .2326$

При цитировании этой статьи сноска на doi обязательна

Закон и правопорядок

уголовно-процессуальные, криминологические, исправительно-трудовые ${ }^{23}$ и криминалистические), а также меры экономические, идеологические, медицинские и т.д. ${ }^{24}$.

Эту же позицию занимали такие ученые, как И.М. Гальперин, В.И. Курляндский ${ }^{25}$, М.И. Ковалев и Ю.А. Воронин, которые полагали, что содержание уголовной политики есть «направление партийной и государственной деятельности по осуществлению социально-политических, экономических мероприятий и выработке оптимальных уголовно-правовых средств, в целях ликвидации преступности в нашей стране» ${ }^{26}$. Эта цитата лишний раз подтверждает политический характер и отражение политических целей в борьбе с преступностью на тот период развития Советского государства.

Говоря о государственной антикримнальной политике той эпохи, П.С. Дагель отмечал, что «Советская уголовная политика - это политика КПСС и Советского государства в сфере борьбы с преступностью. Она определяет основные направления, цели и средства борьбы с преступностью и выражается в партийных документах, нормах советского права и деятельности государственных органов, общественных организаций и всех трудящихся, специально направленной на эту борьбу» ${ }^{27}$. Таким образом, авторы, широко понимающе уголовную политику, подчеркивают неоднородность ее нормативной основы. Они предлагают воздействие на преступность рассматривать как комплексное, включающее нормативные меры различных отраслей права, а также меры, не являющиеся правовыми, но эффективно влияющие на состояние общественной безопасности и правопорядка в этой сфере.

\footnotetext{
23 Здесь и далее приводятся данное и соответствующие ему названия мер, отрасли права, юридической науки на момент издания цитируемых работ. В настоящее время эти названия соответствуют действующему уголовно-исполнительному праву.

${ }^{24}$ Гериензон А.А. Уголовное право и социология. М., 1970. C. 175,179 .

${ }^{25}$ Гальперин И.М., Курляндский В.И. Предмет уголовной политики и основные направления ее изучения // Основные проблемы борьбы с преступностью. М., 1975. С. 12.

${ }^{26}$ Ковалев М.И., Воронин Ю.А. Криминология и уголовная политика. Свердловск, 1980. С. 8.

${ }^{27}$ Дагель П.С. Значение XXVI съезда КПСС для советской уголовной политики // Проблемы повышения эффективности борьбы с преступностью. Иркутск, 1983. С. 5.
}

Представители второго подхода (С.В. Бородин, А.Э. Жалинский, Н.И. Загородников, И.А. Исмаилов, Н.И. Стручков) считают, что только специальные меры воздействия на преступность, которые основываются на уголовном, уголовно-процессуальном и исправительно-трудовом законодательстве, с привлечением данных науки, включая криминологию и криминалистику, составляют это понятие ${ }^{28}$. Н.И. Загородниковым и Н.А. Стручковым предложено следующее определение уголовной политики: «Уголовная политика представляет собой такое направление советской политики, в рамках которого формируются исходные требования борьбы с преступностью посредством разработки и осуществления широкого круга предупредительных мер, создания и применения правовых норм материального, процессуального и исполнительного уголовного права, устанавливающих криминализацию и пенализацию, а когда нужно, декриминализацию деяний, а также посредством определения круга допустимых в борьбе с преступностью мер государственного принуждения» ${ }^{29}$. Следует отметить, что основной акцент в этом определении сделан на исходных требованиях, т.е. принципах борьбы с преступностью, что представляется весьма важным. В позиции других исследователей проблем уголовной политики прослеживается аналогичный подход. Л.Д. Гаухман и Ю.И. Ляпунов писали, что «советская уголовная политика - это основные принципы, направления и перспективы охраны социалистических общественных отношений от преступных посягательств (борьбы с преступностью), базирующиеся на познании объективных закономерностей развития общества в исторически определенный период времени и соответствующие сущности социально-экономической формации» ${ }^{30}$. С определенной спецификой опреде-

\footnotetext{
${ }^{28}$ Стручков Н.А. Исправительно-трудовая политика и ее роль в борьбе с преступностью. Саратов, 1970. С. 4-5; Загородников Н.И. Советская уголовная политика. М., 1979. С. 8-10; Жалинский А.Э. Содержание уголовной политики // Уголовная политика в борьбе с преступностью. Свердловск, 1986. С. 12-18; Бородин С.В. Борьба с преступностью: теоретическая модель комплексной программы. М.: Наука, 1990. С. 4; Исмаилов И.А. Преступность и уголовная политика (актуальные проблемы организации борьбы с преступностью). Баку, 1990. С. 101.

29 Загородников Н.И., Стручков Н.А. Направления изучения советского уголовного права // Советское государство и право. 1981. № 7. C. 4.

${ }^{30}$ Гаухман Л.Д., Ляпунов Ю.И. Понятие советской уголовной политики и ее основные направления. М., 1980. С. 4
} 
DOI: $10.7256 / 1811-9018.2013 .9 .2326$

При цитировании этой статьи сноска на доі обязательна

\section{Право и политика 9 (165) • 2013}

ляет уголовную политику Н.А. Беляев. В одной из своих работ он отмечает, что уголовная политика осуществляется путем применения наказания или заменяющих наказание мер административного или общественного воздействия к лицам, совершившим преступные посягательства, а также путем предупреждения преступлений при помощи угрозы применения наказания ${ }^{31}$.

И.А. Исмаилов охарактеризовал уголовную политику как «направление деятельности государства, осуществляемой на уровне политического руководства, управления, принятия и реализации конкретных решений и имеющей основным назначением определение и проведение в жизнь задач, форм и содержания целенаправленных мер борьбы с преступностью (воздействия на нее), организацию и обеспечение оптимального функционирования и развития этой системы на надлежащей идеологической, правовой, информационной, ресурсной базе и во взаимодействии с другими социальными системами» ${ }^{32}$.

C.C. Босхолов под уголовной политикой понимает: 1) государственную политику (доктрину) борьбы с преступностью, выраженную в соответствующих директивных актах (законах, указах Президента, постановлениях Правительства); 2) научную теорию и синтез соответствующих политических, социологических и правовых знаний; 3) особый вид социальной деятельности, направленной на активное, наступательное противодействие преступности и другим правонарушениям ${ }^{33}$.

Заслуживает внимания точка зрения А.И. Коробеева, А.В. Усса и Ю.В. Голика, утверждавших, что «советская уголовная политика в традиционном ее понимании есть генеральная линия, определяющая основные направления, цели и средства воздействия на преступность путем формирования уголовного, уголовно-процессуального, исправительно-трудового законодательства, практики его применения, а также путем выработки и ре-

${ }^{31}$ Беляев Н.А. Уголовно-правовая политика и пути ее реализации. Ленинград: Издательство Ленинградского университета, 1986. C. 15 .

${ }^{32}$ Исмаилов И.А. Преступность и уголовная политика (актуальные проблемы организации борьбы с преступностью). Баку, 1990. С. 124.

${ }_{33}$ Босхолов С.С. Основы уголовной политики: конституционный, криминологический, уголовно-правовой и информационный аспекты. - М.: ЮрИнфоР, 1999. - С. 32. ализации мер, направленных на предупреждение преступлений» ${ }^{34}$.

И.Э. Звечаровским сформулировано следующее определение: «Уголовная политика - это выработанное государством и основанное на объективных законах развития общества направление деятельности специально уполномоченных на то государственных органов и организаций по охране прав и свобод человека и гражданина, общества и государства в целом от преступных посягательств путем применения наказания и других мер уголовно-правового характера к лицам, их совершившим, а также посредством предупреждения преступлений при помощи правового воспитания, угрозы применения уголовного наказания и мер профилактики индивидуального и специально-криминологического характера» ${ }^{35}$. Данное определение подтверждает, что содержание уголовной политики не исчерпывается только уголовным законодательством. Хотя именно уголовное законодательство выступает материально-правовым основанием, для уголовно-процессуальной политики. И именно уголовное законодательство, закрепляя совершенно определенные виды мер уголовно-правового характера, основания, принципы и порядок их применения, задает основные параметры содержания иных правовых отраслей криминального цикла, направленных на борьбу с преступностью и обеспечение общественной безопасности.

Рассуждая об уголовной политике, необходимо отметить главное - ее ведущую роль по отношению к материальным и процессуальным отраслям права криминального цикла, применение норм которых является одной из форм реализации уголовной политики.

Уголовно-правовая, уголовно-процессуальная и уголовно-исполнительная отрасли являются центральной составляющей уголовной политики. Однако их создание и успешное функционирование (применение), выработка и реализация государственных установок в сфере обеспечения правопорядка, борьбы с преступностью и обеспечения безопасности личности, разработка и организация предупреждения преступности и

\footnotetext{
${ }^{34}$ Коробеев А.И., Усс А.В., Голик Ю.В. Уголовно-правовая политика: тенденции и перспективы. Красноярск, 1991. С. 7.

35 Звечаровский И.Э. Современное уголовное право России: понятие, принципы, политика. СПб.: Издательство «Юридический центр Пресс», 2001. С. 74.
} 
ресоциализация преступников должны строиться на полинормативной основе ${ }^{36}$.

Представляется, что выделение отдельных политик - уголовно-правовой, уголовно-процессуальной, уголовно-исполнительной и т.д., нецелесообразно. Очевидно, речь должна идти о реализации единой уголовной политики в различных подсистемах. Таким образом, к подсистемам, обеспечивающим правовой аспект единой уголовной политики, относятся:

1) уголовно-правовая;

2) уголовно-процессуальная;

3) уголовно-исполнительная.

Отдельные авторы в уголовную политику включают в качестве подсистемы административноправовую политику государства ${ }^{37}$, о которой будет сказано позже.

Уголовно-правовая политика охватывает области уголовного правотворчества, совершенствования уголовного законодательства, практики применения уголовно-правовых мер борьбы с преступностью. В настоящее время она играет роль определения преступного и непреступного, выступает в качестве правовой основы процессов криминализации и пенализации.

Уголовно-процессуальная политика регулирует область процессуального правотворчества, совершенствования уголовно-процессуального законодательства и практики применения различных процессуальных форм и средств борьбы с преступностью, а также управления этой практикой.

Область правотворчества в сфере исполнения уголовного наказания, исправления осужденных, повышения эффективности практики исполнения уголовного наказания, а также управления этой практикой охватывает уголовно-исполнительная (пенитенциарная) политика.

Говоря об уголовной политике, необходимо подчеркнуть комплексный характер уголовной политики - не должно быть отдельно уголовной политики в сфере уголовного права, уголовной политики в сфере уголовно-процессуального права, уголов-

\footnotetext{
${ }^{36}$ Лесников Г.Ю. Уголовная политика современной России (методологические, правовые и организационные аспекты). Дисс. докт. юрид. наук. М. 2005. С. 37 - 38.

37 Лесников Г.Ю. Уголовная политика современной России (методологические, правовые и организационные аспекты). Дисс. докт. юрид. наук. М. 2005. С. 44.
}

ной политики в сфере уголовно-исполнительного права. Уголовная политика на законодательном уровне воплощается в уголовном - материальном, процессуальном, исполнительном - праве ${ }^{38}$. Мы не считаем, однако, что «изменение материального права должно обязательно влечь соответствующие изменения на процессуальном и исполнительном уровнях», как утверждает Г.Ю. Лесников ${ }^{39}$.

Авторы, включающие административно-правовую политику в качестве подсистемы уголовной политики, утверждают, что она (административно-правовая политика) охватывает, в частности, область административного правотворчества и применения на практике административно-правовых мер по борьбе с преступностью и ее «фоновыми» явлениями (пьянством, наркотизмом, бродяжничеством, попрошайничеством, безнадзорностью несовершеннолетних, проституцией и др.), управления этой практикой ${ }^{40}$. Административно-правовая подсистема является важным фактором поддержания в обществе правопорядка. Речь идет здесь не обо всем административном законодательстве, а лишь о тех его частях, которые непосредственно направлены на борьбу с преступностью ${ }^{41}$.

Науки уголовного права, процесса и т.д. имеют свои уголовно-политические аспекты. Но, ни одна из них, ни все они вместе не охватывают всей проблематики уголовной политики. Только наука уголовной политики может охватить всю систему государственных и общественных мер борьбы с преступностью как единый комплекс и тем самым решить проблему единства уголовной политики, ее координированности, плановости и эффективности» ${ }^{42}$. Уголовная политика должна развиваться как самостоятельная отрасль знаний и самостоятельная учебная дисциплина ${ }^{43}$.

\footnotetext{
38 Лесников Г.Ю. Уголовная политика современной России (методологические, правовые и организационные аспекты). Дисс. докт. юрид. наук. М. 2005. С. 283.

39 Там же.

${ }^{40}$ Там же. С. 44.

${ }^{41}$ Миньковский Г.М., Ревин В.П. Уголовная политика и ее реализация в деятельности органов внутренних дел // Методические материалы. М.: Академия МВД России, 1996.С.5.

42 Дагель П.С. Проблемы советской уголовной политики. Владивосток: Дальневосточн. ун-т, 1982. С. 17.

${ }^{43}$ Исмаилов И. А. Уголовная политика и уголовная политология // Учен. зап. - Азербайджанский университет. Серия юридических наук. Баку, 1976. Вып. 1. С. 41-52
} 
DOI: 10.7256/1811-9018.2013.9.2326

При цитировании этой статьи сноска на dоі обязательна

\section{Право и политика $9(165) \cdot 2013$}

Л.В. Баринова, Н.Э. Мартыненко и В.П. Ревин справедливо отмечают, что анализ уголовно-правовой ситуации представляет собой аналитическое обобщение результативности процессуальной и оперативно-розыскной деятельности по правовому воздействию на преступность ${ }^{44}$. Целью этого анализа, в отличие от анализа криминальной ситуации, является определение влияния отдельных правовых средств (или их совокупности) на состояние, тенденции, динамику преступности в целом или отдельных ее видов. Иными словами, «уголовноправовая ситуация - это соотношение нормативно запрещенных видов преступного поведения и фактически совершенных общественно-опасных деяний, а также конкретная обстановка в сфере воздействия на преступность путем применения наказания и заменяющих его мер, предусмотренных уголовным законом» ${ }^{45}$. При этом изучается влияние не собственно норм материального уголовного права, а всего нормативного комплекса, направленного на борьбу с преступностью.

Уголовно-правовая ситуация современной России, характеризующая состояние преступности, уровень борьбы с нею, результативность процессуальной и оперативно-розыскной деятельности по правовому воздействию на преступность, а также определение влияния отдельных правовых средств (или их совокупности) на состояние, тенденции, динамику преступности в целом или отдельных ее видов, полностью отражает современное развитие российской государственности и российского общества ${ }^{46}$.

Предупреждение и борьба с преступностью должны осуществляться на основе действующего уголовного, уголовно-процессуального и уголовноисполнительного законодательства. Центральной составляющей уголовной политики являются уголовно-правовая, уголовно-процессуальная и уголовно-исполнительная отрасли. Однако их создание и успешное функционирование (применение), выра-

${ }^{44}$ См.: Баринова Л.В., Мартыненко Н.Э., Ревин В.П. Словарь терминов и схем по курсам: «Уголовная политика и ее реализация в деятельности органов внутренних дел» и «Организация профилактической деятельности органов внутренних дел». М.: Академия управления МВД России, 2000. С. 37.

${ }^{45}$ Баринова Л.В., Мартыненко Н.Э., Ревин В.П. Указ. раб. С.37.

46 Лесников Г.Ю. Уголовная политика современной России (методологические, правовые и организационные аспекты). Дисс. докт. юрид. наук. М. 2005. С. 137. ботка и осуществление государственных директив в сфере обеспечения правопорядка, борьбы с преступностью и обеспечения безопасности личности, разработка и организация предупреждения преступности и ресоциализация преступника должны строиться на полинормативной основе. Уголовная политика как часть внутригосударственной политики должна строиться и осуществляться на основе политических директив, норм права, морали (нравственности), религиозных норм, обычаев, а также корпоративных норм.

Уголовная политика полинормативна. Нормы материального уголовного права, процессуальные формы деятельности уголовной юстиции и правовые представления людей образуют некоторое единство, «модель уголовной политики». В пределах одной исторической ситуации и даже в условиях действия одной и той же правовой системы могут сосуществовать несколько разновременных действующих моделей уголовной политики, в каждой из которой утверждается специфическое понимание личности преступника, сущности наказания, перспектив и задач уголовно-правового воздействия. Без понимания этих различий трудно объяснить выбор законодателем конкретных приемов криминализации, предпочтение тех или иных видов наказания, попытки совершенствования институтов уголовного права и т. д.

Обеспечение борьбы с преступностью уголовно-правовыми и уголовно-процессуальными средствами составляет важнейшее звено современной государственной политики в сфере правоохранительной деятельности ${ }^{47}$.

Принципиально важный этап судебной реформы оказался тесно связанным с введением в действие нового Уголовно-процессуального кодекса Российской Федерации. Через пять с половиной лет после вступления в силу УК РФ 1996 года были существенным образом изменены условия, в которых правоохранительные органы выполняют свои функции по обеспечению общественной безопасности и борьбе с преступностью. Вступила в действие система норм вновь принятого Уголовно-процессуального кодекса, предъявляющего жесткие требования к

\footnotetext{
${ }^{47}$ См.: Александров А.И. Уголовная политика и уголовный процесс в российской государственности: история, современность, перспективы, проблемы / Под ред. В.З. Лукашевича. СПб.: Изд-во С.-Пб. ун-та, 2003. - 562 с.
} 
повседневной работе по пресечению, раскрытию и расследованию преступлений ${ }^{48}$.

Разумеется, усвоение правоохранительными органами новых норм уголовно-процессуального законодательства и работа на их основе потребовала определенного промежутка времени.

Одним из наиболее важных направлений совершенствования уголовной политики при ее правовом обеспечении является дальнейшая демократизация правовой системы борьбы с преступностью, и, прежде всего, уголовного, уголовно-процессуального и уголовно-исполнительного законодательства, практики его применения, а также деятельности органов уголовной юстиции. Данное направление уголовной политики находит отражение и закрепление в уголовном, уголовнопроцессуальном, уголовно-исполнительном и других отраслях законодательства.

На сегодняшний день можно признать, что уголовная политика представляет собой самостоятельную научную теорию. Она является межотраслевой и включает в себя исследования в области законодательства криминального цикла (уголовное, уголовно-процессуальное и уголовно-исполнительное). Областью уголовно-политической теории охватываются также исследования сферы юридических наук, не являющихся отраслевыми, но имеющих свой предмет и непосредственное отношение к борьбе с преступностью.

Законов, сферой специального регулирования которых было бы определение официальной стратегии борьбы с преступностью или конкретных векторов уголовной политики, в нашей стране до сих пор принято не было.

В литературе высказано мнение о том, что «основные положения уголовной политики должны приниматься на высшем государственно-политическом уровне в виде отдельного Закона об основах уголовной политики Российской Федерации. В этом документе должны быть зафиксированы принципы и основные начала уголовной политики: политическое и политико-правовое, специальнопрофилактическое, уголовно-правовое, уголовно-процессуальное, уголовно-исполнительное

\footnotetext{
48 См.: Федеральный закон от 18.12.2001 г. № 177-Ф3 «О введении в действие Уголовно-процессуального кодекса Российской Федерации» // Российская газета. - 2001. - 22 декабря. - № 249.
}

применительно к стратегическим приоритетам в борьбе с преступностью» ${ }^{49}$.

Исследуя феномен уголовной политики, нельзя обойти вниманием появление в научной и учебной юридической литературе смежных с ним терминов и понятий.

Так, например, В.Ф. Щербаков, изучающий государственную политику противодействия экономической преступности, определяет ее как систему «согласованных и взаимосвязанных организационно-правовых, организационно-практических, экономических, идеологических, социально-профилактических, оперативно-розыскных и других мер, направленных на соблюдение законодательства, предупреждение, выявление и раскрытие преступлений, применение принудительно-правовых методов и средств воздействия на лиц, совершивших противоправные деяния в сфере экономики, перевоспитание осужденных, осуществляемое на основе действующего законодательства, правовой теории законодательными, исполнительными, правоохранительными и другими государственными органами» ${ }^{50}$.

М.П. Клеймёнов, известный своими криминологическими исследованиями экономической преступности, предлагает введение в научный оборот понятия криминологической политики. По его словам, это «научно обоснованная, соответствующая международным стандартам и требованиям национального законодательства, целеустремленная и системная деятельность государственных и муниципальных органов, политических институтов, субъектов предпринимательской деятельности, общественных организаций, религиозных объединений и граждан по сокращению преступности и декриминализации общественных отношений социальными и правовыми средствами, обеспечению защищенности жизненно важных интересов личности, общества и государства от внутренних и внешних угроз криминального характера» ${ }^{51}$.

По мнению автора, уголовная политика выступает частью криминологической, поскольку

\footnotetext{
49 Лесников Г.Ю. Уголовная политика современной России (методологические, правовые и организационные аспекты). Дисс. докт. юрид. наук. М. 2005. С. 195.

${ }^{50}$ Щербаков В.Ф. Теоретические основы государственной политики противодействия экономической преступности. Нижний Новгород. 2005. С. 47.

${ }^{51}$ Клеймёнов М.П. Криминология: учебник. М. 2008. С. 225.
} 
DOI: 10.7256/1811-9018.2013.9.2326

При цитировании этой статьи сноска на doi обязательна

\section{Право и политика $9(165) \cdot 2013$}

последняя опирается еще и на социальную политику. Любая составная часть уголовной политики (уголовно-правовая, уголовно-процессуальная, уголовно-исполнительная, административноправовая, оперативно-розыскная политика) должна быть нацелена на ограничение преступности, иными словами, обладать антикриминогенным потенциалом, соответствовать направлению криминологической политики и с этой точки зрения оцениваться криминологами ${ }^{52}$.

Таким образом, большинство авторов рассматривают уголовную политику как направление государственной деятельности, определяющее стратегию и тактику борьбы с преступностью на базе уголовного материального, процессуального и исполнительного права.

Это подтверждают и данные опроса сотрудников органов внутренних дел. Примерно 75\% опрошенных руководящих работников органов внутренних дел согласны с подобной позицией об уголовной политике $\mathrm{e}^{53}$.

Подводя итог вышеизложенному, считаем, что уголовная политика - это складывающаяся на основе соответствующей научной теории стратегия государственных органов по созданию и применению согласованных между собой норм уголовного, уголовно-процессуального и уголовно-исполнительного законодательства (законодательства криминального цикла), устанавливающих криминализацию и декриминализацию деяний, порядок досудебного и судебного производства по делам о совершенных преступлениях и порядок и условия исполнения и отбывания наказаний.

\section{Библиография:}

1. Гогель С.К. Курс уголовной политики в связи с уголовной социологией. СПб., 1910.

2. Чубинский М.П. Курс уголовной политики. СПб., 1912.

3. Владимиров Л.Е. Курс уголовного права. М., 1908.

4. Feuerbach A. Versuch einer Criminaljurisprudenz des Koran, 1804.

\footnotetext{
52 Там же.

53 Лесников Г.Ю. Проблемы реализации уголовной политики. М. 2005. C. 12
}

5. Лунеев В.В. Преступность XX века. Мировые, региональные и российские тенденции. М.: Издательство НОРМА, 1999.

6. Пионтковский А.А. Наука уголовного права: его предмет, задачи и значение. Одесса, 1892.

7. Пионтковский А. А. Марксизм и уголовное право. - 2-е изд. - М.: Юрид. изд-во НКЮ РСФСР, 1929.

8. Пионтковский А. А. Советское уголовное право: Общая часть. М.: Юрид. изд-во НКЮ, 1928.

9. Волков Г.И. Классовая природа преступллений и советское уголовное право. М.: Советское законодательство, 1935.

10. Волков Г.И. Уголовная политика эпохи промышленного капитализма. М.: Сов. законодательство, 1932.

11. Булатов С.Я. Уголовная политика эпохи империализма. М.: Сов. законодательство, 1933.

12. Карательная политика капиталистических стран. М.: Сов. законодательство, 1933.

13. Пионтковский А.А. Уголовная политика Японии. М.: Сов. законодательство, 1936.

14. БСЭ. М., 1956. Т. 43.

15. Исмаилов И.А. Уголовная политика как сложная система // Учен. зап. / Азербайджанский университет. Серия юридических наук. Баку, 1975. Вып. 1.

16. Антонян Ю.М. Социалистическая законность и уголовная политика // XXVI съезд КПСС и укрепление законности и правопорядка. М.: ИГП АН СССР, 1982.

17. Лесников Г.Ю. Уголовная политика современной России (методологические, правовые и организационные аспекты). Дисс. докт. юрид. наук. М. 2005.

18. Загородников Н.И., Стручков Н.А. Направления изучения советского уголовного права // Советское государство и право. 1981. № 7.

19. Герцензон А.А. Уголовное право и социология. M., 1970.

20. Гальперин И.М., Курляндский В.И. Предмет уголовной политики и основные направления ее изучения // Основные проблемы борьбы с преступностью. М., 1975.

21. Ковалев М.И., Воронин Ю.А. Криминология и уголовная политика. Свердловск, 1980.

22. Дагель П.С. Значение XXVI съезда КПСС для советской уголовной политики // Проблемы 
DOI: 10.7256/1811-9018.2013.9.2326

При цитировании этой статьи сноска на doi обязательна

Закон и правопорядок

повышения эффективности борьбы с преступностью. Иркутск, 1983.

23. Стручков Н.А. Исправительно-трудовая политика и ее роль в борьбе с преступностью. Саратов, 1970.

24. Загородников Н.И. Советская уголовная политика. М., 1979.

25. Жалинский А.Э. Содержание уголовной политики // Уголовная политика в борьбе с преступностью. Свердловск, 1986.

26. Бородин С.В. Борьба с преступностью: теоретическая модель комплексной программы. М.: Наука, 1990.

27. Исмаилов И.А. Преступность и уголовная политика (актуальные проблемы организации борьбы с преступностью). Баку, 1990.

28. Гаухман Л.Д., Ляпунов Ю.И. Понятие советской уголовной политики и ее основные направления. М., 1980.

29. Беляев Н.А. Уголовно-правовая политика и пути ее реализации. Ленинград: Издательство Ленинградского университета, 1986.

30. Босхолов С.С. Основы уголовной политики: конституционный, криминологический, уголовно-правовой и информационный аспекты. - М.: ЮрИнфоР, 1999.

31. Коробеев А.И., Усс А.В., Голик Ю.В. Уголовноправовая политика: тенденции и перспективы. Красноярск, 1991.

32. Звечаровский И.Э. Современное уголовное право России: понятие, принципы, политика. СПб.: Издательство «Юридический центр Пресс», 2001.

33. Миньковский Г.М., Ревин В.П. Уголовная политика и ее реализация в деятельности органов внутренних дел // Методические материалы. М.: Академия МВД России, 1996.

34. Дагель П.С. Проблемы советской уголовной политики. Владивосток: Дальневосточн. ун-т, 1982.

35. Баринова Л.В., Мартыненко Н.Э., Ревин В.П. Словарь терминов и схем по курсам: «Уголовная политика и ее реализация в деятельности органов внутренних дел» и «Организация профилактической деятельности органов внутренних дел». М.: Академия управления МВД России, 2000.

36. Александров А.И. Уголовная политика и уголовный процесс в российской государствен- ности: история, современность, перспективы, проблемы / Под ред. В.З. Лукашевича. СПб.: Изд-во С.-Пб. ун-та, 2003.

37. Федеральный закон от 18.12.2001 г. № 177-ФЗ «О введении в действие Уголовно-процессуального кодекса Российской Федерации» // Российская газета. - 2001. - 22 декабря. - № 249.

38. Щербаков В.Ф. Теоретические основы государственной политики противодействия экономической преступности. Нижний Новгород. 2005.

39. Клеймёнов М.П. Криминология: учебник. М. 2008.

40. Лесников Г.Ю. Проблемы реализации уголовной политики. М. 2005.

\section{References (transliteration):}

1. Gogel' S.K. Kurs ugolovnoy politiki v svyazi s ugolovnoy sociologiey. SPb., 1910.

2. Chubinskiy M.P. Kurs ugolovnoy politiki. SPb., 1912.

3. Vladimirov L.E. Kurs ugolovnogo prava. M., 1908.

4. Feuerbach A. Versuch einer Criminaljurisprudenz des Koran, 1804.

5. Luneev V.V. Prestupnost' HH veka. Mirovye, regional'nye i rossiyskie tendencii. M.: Izdatel'stvo NORMA, 1999.

6. Piontkovskiy A.A. Nauka ugolovnogo prava: ego predmet, zadachi i znachenie. Odessa, 1892.

7. Piontkovskiy A. A. Marksizm i ugolovnoe pravo. -2-e izd. - M.: Yurid. izd-vo NKYu RSFSR, 1929.

8. Piontkovskiy A. A. Sovetskoe ugolovnoe pravo: Obschaya chast'. M.: Yurid. izd-vo NKYu, 1928.

9. Volkov G.I. Klassovaya priroda prestup $\neg$ leniy i sovetskoe ugolovnoe pravo. M.: Sovetskoe zakonodatel'stvo, 1935.

10. Volkov G.I. Ugolovnaya politika epohi promyshlennogo kapitalizma. M.: Sov. zakonodatel'stvo, 1932.

11. Bulatov S.Ya. Ugolovnaya politika epohi imperializma. M.: Sov. zakonodatel'stvo, 1933.

12. Piontkovskiy A.A. Ugolovnaya politika Yaponii. M.: Sov. zakonodatel'stvo, 1936.

13. Ismailov I.A. Ugolovnaya politika kak slozhnaya sistema // Uchen. zap. / Azerbaydzhanskiy universitet. Seriya yuridicheskih nauk. Baku, 1975. Vyp. 1.

14. Antonyan Yu.M. Socialisticheskaya zakonnost' i ugolovnaya politika // XXVI s'ezd KPSS i ukreple- 
DOI: 10.7256/1811-9018.2013.9.2326

При цитировании этой статьи сноска на dоі обязательна

\section{Право и политика $9(165) \cdot 2013$}

nie zakonnosti i pravoporyadka. M.: IGP AN SSSR, 1982.

15. Lesnikov G.Yu. Ugolovnaya politika sovremennoy Rossii (metodologicheskie, pravovye i organizacionnye aspekty). Diss. dokt. yurid. nauk. M. 2005.

16. Zagorodnikov N.I., Struchkov N.A. Napravleniya izucheniya sovetskogo ugolovnogo prava // Sovetskoe gosudarstvo i pravo. 1981. № 7.

17. Gercenzon A.A. Ugolovnoe pravo i sociologiya. M., 1970.

18. Gal'perin I.M., Kurlyandskiy V.I. Predmet ugolovnoy politiki i osnovnye napravleniya ee izucheniya // Osnovnye problemy bor'by s prestupnost'yu. M., 1975.

19. Kovalev M.I., Voronin Yu.A. Kriminologiya i ugolovnaya politika. Sverdlovsk, 1980.

20. Dagel' P.S. Znachenie XXVI s'ezda KPSS dlya sovetskoy ugolovnoy politiki // Problemy povysheniya effektivnosti bor'by s prestupnost'yu. Irkutsk, 1983.

21. Struchkov N.A. Ispravitel'no-trudovaya politika i ee rol' v bor'be s prestupnost'yu. Saratov, 1970.

22. Zagorodnikov N.I. Sovetskaya ugolovnaya politika. M., 1979.

23. Zhalinskiy A.E. Soderzhanie ugolovnoy politiki // Ugolovnaya politika v bor'be s prestupnost'yu. Sverdlovsk, 1986.

24. Borodin S.V. Bor'ba s prestupnost'yu: teoreticheskaya model' kompleksnoy programmy. M.: Nauka, 1990.

25. Ismailov I.A. Prestupnost' i ugolovnaya politika (aktual'nye problemy organizacii bor'by s prestupnost'yu). Baku, 1990.

26. Gauhman L.D., Lyapunov Yu.I. Ponyatie sovetskoy ugolovnoy politiki i ee osnovnye napravleniya. M., 1980.
27. Belyaev N.A. Ugolovno-pravovaya politika i puti ee realizacii. Leningrad: Izdatel'stvo Leningradskogo universiteta, 1986.

28. Bosholov S.S. Osnovy ugolovnoy politiki: konstitucionnyy, kriminologicheskiy, ugolovno-pravovoy i informacionnyy aspekty. - M.: YurInfoR, 1999.

29. Korobeev A.I., Uss A.V., Golik Yu.V. Ugolovnopravovaya politika: tendencii i perspektivy. Krasnoyarsk, 1991.

30. Zvecharovskiy I.E. Sovremennoe ugolovnoe pravo Rossii: ponyatie, principy, politika. SPb.: Izdatel'stvo «Yuridicheskiy centr Press», 2001.

31. Min'kovskiy G.M., Revin V.P. Ugolovnaya politika i ee realizaciya $\mathrm{v}$ deyatel'nosti organov vnutrennih del // Metodicheskie materialy. M.: Akademiya MVD Rossii, 1996.

32. Dagel' P.S. Problemy sovetskoy ugolovnoy politiki. Vladivostok: Dal'nevostochn. un-t, 1982.

33. Barinova L.V., Martynenko N.E., Revin V.P. Slovar' terminov i shem po kursam: «Ugolovnaya politika i ee realizaciya $v$ deyatel'nosti organov vnutrennih del» $\mathrm{i}$ «Organizaciya profilakticheskoy deyatel'nosti organov vnutrennih del». M.: Akademiya upravleniya MVD Rossii, 2000.

34. Aleksandrov A.I. Ugolovnaya politika i ugolovnyy process $\mathrm{v}$ rossiyskoy gosudarstvennosti: istoriya, sovremennost', perspektivy, problemy / Pod red. V.Z. Lukashevicha. SPb.: Izd-vo S.-Pb. un-ta, 2003.

35. Scherbakov V.F. Teoreticheskie osnovy gosudarstvennoy politiki protivodeystviya ekonomicheskoy prestupnosti. Nizhniy Novgorod. 2005.

36. Kleymenov M.P. Kriminologiya: uchebnik. M. 2008.

37. Lesnikov G.Yu. Problemy realizacii ugolovnoy politiki. M. 2005. 